\title{
Śabdapramāna : Hindu contributions to understanding the meaning and function of scripture
}

\author{
Anantanand Rambachan
}

Correspondence: rambacha@stolaf.edu

Philosophy and Asian Studies at Saint Olaf College, Minnesota, USA

\begin{abstract}
The traditions of Hinduism, especially the Vedanta sampradāyas, have developed elaborate and sophisticated arguments for the words of the Vedas as a source of valid knowledge. This study seeks to explicate this rationale, with particular attention to the tradition of Advaita Vedanta. The understanding of scripture as a valid source of knowledge (pramāna) is neglected in the contemporary study of Hinduism, although this approach may lend a fresh perspective to the meaning and significance of sacred texts and a unique way of understanding their authority. Scripture cannot claim exemption from being subject to the same criteria that are utilized to validate other ways of knowing. Scripture as pramāna is a Hindu argument that enriches our understanding of sacred texts and ought to be a prominent point of view in the contemporary discussion of the nature and authority of scripture.
\end{abstract}

\section{Valid means of knowledge}

The term 'scripture' is the one most widely employed to describe the wisdom teachings of the world's religions. Although such a general term is useful for highlighting similarities across religious traditions, this may conceal also radical differences. Such concealing leads to an unfortunate loss of the distinctive understandings of religious traditions and the enrichment that differences make possible. Although the Vedas share similarities with the sacred texts of other traditions, the classical Advaita Vedānta tradition has developed and articulated a distinct argument for their nature and authority. This argument is an elaborate and sophisticated case for the words of the Vedas as a pramāna (source of valid knowledge) and this study seeks to explicate the Advaita rationale. The understanding of scripture as a pramāna is neglected in the contemporary study of Hinduism, although this approach may lend a fresh perspective to the meaning and significance of sacred texts and a unique way of understanding their authority. Scripture as pramāna, is a Hindu argument which enriches our understanding of sacred texts and ought to be a prominent point of view in the contemporary discussion of the nature and authority of scripture.

Valid knowledge (pramā) according to the Advaita (Non-dual) Vedānta tradition is knowledge that conforms to the nature of the object which one seeks to know (vastutantram). Knowing does not offer the same choices that action does, since every action generally presents us with alternative methods for accomplishing a goal. The

(c) 2014 Rambachan; licensee Springer. This is an Open Access article distributed under the terms of the Creative Commons Attribution License (http://creativecommons.org/licenses/by/2.0), which permits unrestricted use, distribution, and reproduction in any medium, provided the original work is properly cited. 
particular choice is dependent on human will and circumstances (purușatantram). Valid knowledge can be generated only by the application of a valid and appropriate means of knowledge, referred to as a pramāna. A pramāṇa, therefore, may be understood to be a means of valid knowledge (pramā). Advaita Vedānta recognizes six valid means of knowledge. These are perception (pratyakșa), inference (anumāna), comparison (upamāna), postulation (arthāpatti), noncognition (anupalabdhi), and word (śabda). As a means of valid knowledge, śabda refers to meaningful sounds, consisting of a single word or a group of words. Although words are used in everyday transactions to convey knowledge of various kinds, the Advaita tradition is specifically interested in the justification of words as a unique and appropriate means of knowledge for revealing the nature of ultimate reality (Brahman). In this context, śabda in Advaita, is synonymous with the Vedas or śruti. Advaita regards the Vedas as a means of valid knowledge that operates through the instrumentality of words.

\section{Śabda in Advaita Vedānta}

One of the most important outcomes of understanding the Vedas as a pramanna is that the argument for their validity cannot be centered on their origin. Although Sankarāchärya regards the Vedas as having their source in Brahman, this is not the cornerstone of his argument for the authority of the texts. He does not argue often for the authority of the Vedas on the basis of Brahman's omniscience. His reason is that such an argument ends up hopelessly circular, since one establishes the omniscience of Brahman from the Vedas and then the authority of the Vedas from brahman's omniscience. Śankarāchärya's principal and important arguments are centered on the nature of the Vedas as a pramāna.

The cornerstone of Sankarāchārya's argument for the authority of the Vedas is that the scripture fulfils the criteria of being a pramāna; that is, a source of valid knowledge. The Advaita tradition proposes that valid knowledge must satisfy two conditions. It must inform us of something which cannot be ascertained through the operation of another means of knowledge and its claims must not be contradicted by anything established through other valid sources, (VP. Ch.1). Novelty (anadhigatatvam) and non-contradictedness (abadhitatvam) are considered to be the crucial characteristics of valid sources of knowledge. We will examine each criterion in turn, beginning with the novelty argument ${ }^{\mathrm{a}}$.

According to Sankarāchārya, the two categories of knowledge, inaccessible to all other pramānas and available only through the Vedas are dharma and Brahman. (BSB 2.1.6) The knowledge of dharma and adharma, that is the relationship between the performance or non-performance of prescribed ritual actions and the unseen results which they produce, is derived from the ritual or karmakānda sections of the Vedas. Śankarāchārya's interest, however, is primarily in the jũāna kānda or the Upanișads that reveal the knowledge of Brahman, the absolute.

The novelty argument implies that the pramānas one selects, in any given situation, must be appropriate to the knowledge that is sought. In fact, it is more correct to suggest that the nature of the object to be known determines the choice of the means of knowledge. Each sense organ, for example, grants us a unique perceptual experience. The color of an object may be known only through the eyes while only the organ of smell reveals its odor. There is a logical interdependence, therefore, between the appropriateness of the means of knowledge and the nature of the entity to be 
known. The cornerstone of Śankarāchārya's case for the Upaniṣads as the valid means for knowing Brahman is grounded in the nature of Brahman. The relationship is between Brahman as the entity to be known and śabda, or words as the means of knowledge.

In making the case for the validity and appropriateness of the words of the Upanișads as the means of knowing Brahman, Sankarāchārya repeatedly discusses the reasons why other means are inapplicable. He tirelessly explains the inability of sense perception to know brahman. Each sense organ is naturally capable of revealing a quality that is appropriate to its own nature. Sound, sensation, form, taste and scent are their respective spheres of functioning. Brahman, however, remains unknowable through any of these because of its uniqueness. Brahman has neither sound, touch, form, taste nor smell and is therefore outside the domain of these sense organs. A Brahman that is apprehended through the senses is, from the Advaita viewpoint, a contradiction. Sankarāchārya rejects the claim that there is a contradiction in the Bhagavadgitā's denial of Brahman as both sat (existent) and asat (non-existent) by interpreting these terms to signify the non-availability of Brahman as an object of sense knowledge.

Objection: Every state of consciousness involves either the consciousness of existence or that of nonexistence. Such being the case, the Knowable should be comprehended either by a state of consciousness accompanied with the consciousness of existence or by a state of consciousness accompanied with the consciousness of nonexistence.

Answer: No; for being beyond the reach of the senses, it is not an object of consciousness accompanied with the idea of either (existence or non-existence). That thing indeed which can be perceived by the senses, such as a pot, can be an object of consciousness accompanied with the idea of nonexistence. Since, on the other hand, the Knowable is beyond the reach of the senses and as such can be known solely through that instrument of knowledge that is called śabda... and is therefore not said to be "sat" or "asat". (BGB 13:12)

In addition to the inherent limitation of the sense organs, there is the impossibility of objectifying Brahman.

The process of empirical knowledge involves a distinction between subject and object, the knower and the known. We know things by making them objects of our awareness and, in this way, they are available for scrutiny and analysis. Knowledge of an object presupposes the subject, the knower. Brahman, however, is the eternal subject. As awareness, it illumines everything, and the entire universe, including mind, body, and sense organs is its object ${ }^{\mathrm{b}}$. It is impossible for the subject to become an object, for in its absence there will be no subject to know the subject is an object.

Even in the state of ignorance, when one sees something, through what instrument should one know that owing to which all this is known? For the instrument of knowledge itself falls under the category of objects. The knower may desire to know, not about itself, but about objects. As fire does not burn itself, so the self does not know itself and the knower can have no knowledge of a thing that is not its object. 
Therefore, through what instrument should one know the Knower owing to which this universe is known and who else should know it? (BUB 2.4.14)

If perception is unsuitable for providing us with the knowledge of Brahman are any of the other four pramānas competent? Sankarāchārya's view is that these sources are more or less dependent on perception for their data and are inapplicable in those areas where perception has no access. Inferential knowledge, for example is derived from discerning the invariable relation between a thing inferred and the ground from which the inference is made. Brahman, however, is not invariably related to any apprehensible or differentiating qualities that can form the ground of an inference. It is impossible, therefore, to infer anything about the absolute.

The Advaita rationale for śabdapramāna invites examination of the assumptions underlying the objects and methods of human knowledge. There is a logical consistency between the nature of Brahman and śabda as the means of knowledge. The Advaita justification for the words of the Upanișads as the valid means of knowing Brahman challenges us to ponder the following questions. How is an entity like Brahman, which has no qualities available for perception or inference, to be known? Can words be a logical source of knowledge for such a reality or is human knowledge limited to objects that can, in some way or another, only be perceived? How can the subject, the knower that can never be objectified, be known?

The second criterion for valid knowledge is non-contradictedness (abadhitatvam). This criterion, as far as Advaita is concerned is the fundamental characteristic and the crucial test of truth. All other tests are seen as conforming to this. An invalid proposition or experience can be refuted on the grounds of being contradicted. The principle of non-contradictedness implies that a cognition, the purpose of which is to reveal reality, is held to be valid until it is falsified by another pramāna. In Śankarāchārya's view, one valid pramāna does not contradict another. Each pramāna reveals knowledge that cannot be obtained by another. Two pramānas whose spheres are entirely different cannot be contradictory. The eyes, which perceive forms, and the ears, which apprehend sounds, are not opposed. It is only when two pramānas deal with the same object and are contradictory that they are opposed.

Śankarāchārya does not deny the capacity of pramānas like perception and inference to produce valid knowledge in their respective spheres in the empirical world. He does not propose also any alternative to valid knowledge, empirical and religious, besides the legitimate pramānas. He states, in fact, that practical affairs will become impossible if the pramānas are regarded as fundamentally perverse.

If you challenge the validity of an inference of the kind not based on a causal relation, all of our activities, including eating and drinking, would be impossible, which you certainly do not desire. We see in life that people who have experienced that hunger and thirst, for instance, are appeased by eating and drinking, proceed to adopt these means, expecting similar results; all these would be impossible. As a matter of fact, however, people who have the experience of eating and drinking infer, on the ground of similarity, that their hunger and thirst would be appeased if they ate and drank again, and proceed to act accordingly. (BUB. 4.3.6.) 
It may be argued that there is a fundamental conflict, from the Advaita standpoint, between the claims of the Upanișads and our ordinary ways of knowing. The Upanișads affirm the ultimate non-duality of reality while our knowledge of the world through the senses is one of duality. Although Advaita does not deny apparent contradiction between the pramānas, it is important to note that it does not invalidate the ability of sources like perception and inference to produce valid knowledge empirically. What is at stake is the ultimate nature of reality. This is an open question that invites interesting discussion between the Advaita tradition and other viewpoints.

For Śankarāchārya, the knowledge of the Vedas is not opposed to fact. He denies, for example, that there is any conflict between śruti and perception with regard to the nature of the self. The claim of the śruti that the self is free from all limitations is not opposed to our perceptual experience. The latter has for its object the self as identified with various limiting adjuncts (upādhis), while the śruti points to the self that is free from all erroneous identification. (BUB. 1.4.7)

The nature of the Vedas as a pramāna along with the criteria of novelty and noncontradictedness imply that the scripture has a very limited sphere of authority. As noted earlier, the scripture is a pramānas for the specific knowledge of dharma and Brahman, which is unavailable through any other sources. It is not authoritative where it reveals information which one may obtain or has obtained from another source of valid knowledge. It is not the primary function of the scripture to disclose matters within the range of human experience, ascertainable through our ordinary means of knowledge. If a śruti statement contradicts a well-established fact of our everyday experience, it cannot be considered authoritative because such a matter would be outside its authority. Śankarāchārya remarkably admits this truth.

Sruti is an authority only in matters not perceived by means of ordinary instruments of knowledge such as pratyakșa or immediate perception; - i.e., it is an authority as to the mutual relation of things as means to ends, but not in matters lying within the range of pratyakșa indeed, śruti is intended as an authority only for knowing what lies beyond the range of human knowledge.... A hundred śruti may declare that fire is cold or that it is dark; still they possess no authority in this matter. (BGB. 18:66)

If śruti did describe fire as being cold or dark, we would be obliged to construe its meaning figuratively, since the purpose of the scripture is not to create anything new or to reverse the nature of anything. The texts are fundamentally revelatory in purpose and are concerned with expressing things as they are.

Things in the world are known to possess certain fixed characteristics such as grossness or fineness. By citing them as examples, the scripture seeks to tell us about some other thing which does not contradict them. They would not cite an example from life if they wanted to convey an idea of something contradictory to it. Even if they did, it would be to no purpose, for the example would be different from the thing to be explained. You cannot prove that fire is cold, or that the sun does not shine, even by citing a hundred examples, for the facts would already be known to be otherwise through another means of knowledge. And one means of knowledge 
does not contradict another, for it only tells us about those things that cannot be known by another means. Nor can scripture speak about an unknown thing without having recourse to conventional words and their meanings. (BUB.2.I.20)

The Advaita tradition is very specific about some of the topics that are not authoritatively revealed in the scripture. It is not the purpose of scripture, for example, to inform us of the order and details about the creation of the world since we neither observe nor are told by the texts that the welfare of human beings depends on this kind of knowledge. It is not also the concern of scripture to describe the nature of the human being with regard to such characteristics that are available for observation.

The role of śabdapramāna in Advaita is not, however, merely to inform us in an inconsequential manner of the nature of Brahman. The knowledge of the absolute resolves a fundamental human predicament and the case for the pramanna is integrally connected with its ability achieve this. Although it is not offered as a formal characteristic of valid knowledge like novelty and non-contradictedness, Śankarāchārya repeatedly alludes to the fruitfulness and adequacy of the sentences of the Upanishads as an additional argument for their validity as a pramāna. How can words be a fruitful and adequate solution to a problem? It depends, of course, on the nature of the problem and this argument is also at the heart of the Advaita claim.

The case for the adequacy of the words of the Upanișads is based on the argument that these words are not required to create Brahman or even to prove the existence of Brahman. Words alone cannot bring a non-existent entity into existence and, in this case, they are not required to do so. There are several important and interesting discussions in Sankarāchārya's commentaries that are relevant to this issue.

In his introduction to the Brahmasūtras, Śankarāchārya raises an objection to the superimposition argument. The objector's view is that superimposition is possible only on something that is available for sense perception. In the erroneous apprehension of a rope for a snake, for example, at least the outline of rope is seen. How can anything, however, be superimposed on Brahman that is not an object of perception? In his reply to this objection, Sankarāchārya contends that even though Brahman is not an object of perception, it is not entirely unknown and wrong attribution is possible.

The Self is not absolutely beyond apprehension, because it is apprehended as the content of the concept "I", and because the Self, opposed to the non-Self, is well known in the world as an immediately perceived (i.e., self-revealing entity).

(BSB Introduction)

Elsewhere, the objector asks whether Brahman is known or unknown (BSB.1.1.1). The point of the query here is that if Brahman is known, there is no need for a means of knowledge or for an inquiry to ascertain its nature. If, on the other hand, Brahman is entirely unknown, that is not even the object of a desire to know, then it cannot become the subject for any kind of inquiry. Śankarāchārya denies that Brahman is entirely unknown.

Besides, the existence of Brahman is well known from the fact of Its being the Self of all; for everyone feels that his Self exists, and he never feels, "I do not exist". Had there been no general recognition of the existence of the Self, everyone would have felt, 'I do not exist'. And that Self is Brahman. (BSB.1.1.1) 
If Brahman as the ätman is thus known, one may ask, is not inquiry into the words of śruti redundant? Śankarāchārya's response is to suggest that the knowledge, which we possess, is only of a general nature and the true and distinctive nature of the ätman remains unknown. This lack of distinctive knowledge is the cause, according to Śankarāchārya, of different and conflicting views about the nature of the ātman.

In fact, wrong attribution or superimposition occurs only where knowledge is of a general nature and lacks specificity. In the rope-snake analogy, an object is perceived as existing, but its particular nature is incorrectly ascertained. The qualities of the snake are then attributed to the rope. In the case of the atman, that 'I exist' and 'I know' are self-revelatory. Upon this existence (sat) and awareness (cit), the limited qualities of the body, sense organs and mind are wrongly attributed, and the ätman is taken to be mortal and finite. In other words, the qualities of the non-self are, through ignorance, erroneously superimposed on the self.

Clearly, from Sankarāchārya's standpoint, the problem does not involve the knowledge of an entirely unknown, unrevealed or remote Brahman. It is one of incomplete and erroneous knowledge of an ever-available and self-manifesting entity. The function of the words of the Upanișads lies primarily in the negation of attributes imposed through ignorance on Brahman. The Upanishads do not reveal an unknown being. They impart correct knowledge about a self that is immediately available but whose nature is misunderstood.

One of the important reasons for emphasizing the immediate availability of the atman, and clarifying the nature of the ignorance pertaining to it, is that it establishes the possibility of the words of the Upanișads giving rise to direct and immediate knowledge. The challenge is not one of creating anything new, but of understanding what is always available. Sankarāchārya accepts that the knowledge derived through words is not a fruitful end in itself if the object about which are informed is not yet in existence or not immediately available. If the object is available but misapprehended, like Brahman, correct knowledge through the words of a valid source is adequate.

The attainment of the Self cannot be, as in the case of things other that It, the obtaining of something not obtained before, for here there is no difference between the person attaining and the object attained. Where the Self has to obtain something other that Itself, the Self is the attainer and the non-Self is the object attained. This, not being already attained, is separated from acts such as producing and is to be attained by the initiation of a particular action with the help of auxiliaries. And the attainment of something new is transitory, being due to desire and action that are themselves the product of a false notion, like the birth of a son etc. in a dream. By the very fact of Its being the Self, It is not separated by acts such as producing. But although it is always attained, It is separated by ignorance only. (BRUB 1.4.7)

The above argument is the basis for Śankarāchārya's important distinction between action (karman) and knowledge (jñāna). Action is a correct and appropriate solution where the problem involved is the accomplishment of something unaccomplished. Knowledge, on the other hand, is adequate for the accomplishment of the already accomplished, and it is clear from Śankarāchārya's analysis that he sees the attainment of brahman to be of this kind. Sankarāchārya's case for śabdapramāna is grounded in 
his demonstration of an interrelationship between the nature of Brahman and the means through which it can be known as well between ignorance as the fundamental problem and knowledge as the solution. The means of knowledge, in other words, is both logical and adequate.

In opposition to the Pūrva Mīmāmsā school of Vedic exegesis, who contend that only scriptural injunctions inculcating the performance of acceptable acts and prohibitions instituting restraint from forbidden actions are direct and independent in authority, Sankarāchārya argues for the independent authority of the sentences of the Upanișads. These sentences do not merely serve the injunctions by praising their contents.

Śankarāchārya does not accept that sentences cannot have a factual referent or significance. He points out that even though a sentence might have its ultimate purport in initiating some activity, it does not thereby cease to communicate valid factual information. Even as a person travelling to a destination perceives the existence of leaves and grass at the side of the road, a statement might have its aim in activity, but its factual content is not thereby invalidated (BSB1.3.33). Replying to the claim that mere factual statements that neither persuade us into activity nor dissuade us from it are fruitless, Śankarāchārya contends that:

[T] he test of the authority or otherwise of a passage is not whether it states a fact or an action, but its capacity to generate certain and fruitful knowledge. A passage that has this is authoritative and one that lacks it is not (BUB.1.4.7).

He never tires of continuously affirming the independent fruitfulness of the Upanișad sentences. These sentences, by helping us to distinguish the self from the non-self, release us from the sorrow of taking ourselves to be incomplete and finite beings (BSB. 1.1.4).

Is or is not certain and fruitful knowledge generated by passages setting forth the nature of the Self, and if so, how can they lose their authority? Do you not see the result of knowledge in the removal of evils which are the root of transmigration, such as ignorance, grief, delusion, and fear? Or do you not hear those hundreds of Upanishadic texts such as, "Then what delusion and what grief can there be for the one who sees unity"? (Isa Upanișad 7; BSB. 1.4.7)

Sankarāchārya points also to the transformed life of the knower of Brahman as further evidence of the fruitfulness of knowledge gained through the words of the Upanișad:

For one who has realized the state of unity of the Self and Brahman, it cannot be proved that his mundane life continues just as before; for this contradicts the knowledge of the unity of brahman and the Self arising from the Vedas which are a valid means of knowledge. From noticing the fact that a man can have sorrow, fear, etc. as a result of identifying himself with the body etc., it does not follow that this very man will have sorrow etc., contingent on false ignorance, even when his self identification with the body etc., ceases after realization of the unity of Brahman and the Self, arising from the Vedas which are a valid means of knowledge (BSB. 1.1.4). 
Liberation, being identical with Brahman, is ever accomplished and eternal. The function of knowledge lies in the removal of obstacles.

In Sankarāchärya, the argument for the validity of the Vedas as a pramanna is constructed on the basis of novelty, non-contradictedness and fruitfulness. The argument for novelty ensures that the pramāna is not redundant and does not merely inform us of what can he known from other sources. Non-contradictedness is concerned with truth and validates the correspondence between the claims of the pramanna and reality. Valid knowledge corresponds to the object that one seeks to know and is not subject to the choices of the knower. Fruitfulness is not an independent criterion of valid knowledge, since a false cognition may lead to some gain. Combined with novelty and non-contradictedness, however, it points to the pragmatic nature of the pramanna to transform the self-understanding of the inquirer and resolve life's dilemma. Śankarāchārya's case for the authority of the Vedas, therefore, rests on arguments demonstrating a connection between the nature of Brahman, the inappropriateness of traditional ways of knowing (viz. perception and inference), and the appropriateness of the words of the Upanișads. The knowledge gained from these words about the nature of the self is adequate since the problem is one of misunderstanding and there is experiential evidence of the fruitfulness of this wisdom.

We must ask, however, whether the Advaita claim for the Vedas as the valid source of our knowledge about Brahman does not also have a circular character of its own. In other words, the Vedas inform us of the nature of Brahman and also of their authoritative status as the pramanna for the knowledge of Brahman. We learn from the Vedas that Brahman does not have any quality that may be apprehended by the sense organs and that it is the eternal subject that cannot be objectified. Words, therefore, are the only medium of knowledge. Is this different from any other claim that can neither be refuted nor verified? If no other pramāna is applicable to inquiry into the nature of Brahman, how do we make any extraVeda evaluation?

This is an important question that cannot be left unaddressed and there are, at least, two significant observations to be made. The first is an argument encountered earlier. The definition of the Vedas as a pramāna means that its teachings cannot contradict what we know about the nature of reality through other valid pramānas. The Vedas, in this sense, are subject to the critique and assessment of other pramānas and cannot propound contradictory and untrue claims. Second, and perhaps most important, Advaita welcomes the use of other pramannas into the inquiry about the nature of Brahman, even while admitting the authority of the Vedas. The reason is that Brahman, the central reality of this inquiry, is readily available and not outside of human experience. As Śankarāchārya puts it: "[T]he existence of Brahman is well known from the fact of Its being the Self of all; for everyone feels that his Self exists, and he never feels, 'I do not exist'. Had there been no general recognition of the existence of the Self, everyone would have felt, 'I do not exist'. And that Self is Brahman". (BSB 1.1.1) The matter for inquiry is the nature of the self and not its existence and such inquiry is open, therefore, to a role for other pramānas. Sankarāchārya admits that this is not the case where other teachings of the Vedas are concerned. In the case of Vedic instructions and injunctions for the performance of specific rites and rituals, 
there is no role for other pramānas. The result lies in the future and is not available for immediate inquiry. The rational connection between a particular ritual and its result is not obvious and does not lend itself to inquiry through other pramānas. The Vedic claim therefore, that Brahman is a unique reality, to be known by a unique means of knowledge cannot be treated as being identical to religious claims that cannot be verified or refuted.

\section{Conclusion}

Perhaps the most interesting and compelling consequence of defining the scripture as a pramanna is that it cannot claim exemption from being subject to the same criteria which are employed to establish the validity of other sources of knowledge. Novelty and non-contradictedness, as we have seen, are the characteristics of valid knowledge in Advaita. This places the scripture in the wider stream of discourse about the nature of reality and is opposed to the compartmentalization of human knowledge. The view of scripture as pramāna helps overcome the sharp dichotomies between the methodologies of religion and science. The range of discussion partners in the commentaries of classical exponents, like Śankarāchārya, is exemplary and ought to encourage even greater inclusivity.

The view that each pramanna has a unique sphere of authority of other valid sources has helped the Hindu tradition to avoid the sorts of conflict between religion and the empirical and behavioral sciences which have hampered constructive dialogue between religion and these disciplines. Religion ought not to claim authority in those fields of inquiry where its methods and sources are inappropriate. At the same time, the Advaita understanding of the nature of pramanna calls for a similar acknowledgement of the limits of empirical modes of inquiry.

The understanding of scripture as a pramāna enables us also to employ the tools of contemporary historical, critical methods of inquiry to study scripture, while affirming the authoritative significance of the texts. Here also, the pramanna criteria of novelty and non-contradictedness become very important. For every teaching in the Vedas we may indeed ask two fundamental questions. First, is this teaching novel or can it be known through another source? If it is something that can be known through another, then the Vedas are not its authority. Second, does it contradict any truths established by other valid pramannas? If it does, then such Vedic sentences are not authoritative and we may have to find other ways of understanding them.

\section{Endnotes}

a The study deals primarily with the perspective of Śankarāchārya, while acknowledging that Advaita commentators are not unanimous on the nature and role of the Upanișads as a source of knowledge about Brahman.

${ }^{\mathrm{b}}$ It is important to note here that the mind and its contents, from the standpoint of Brahman as the self, are all objects. Objects, in this sense, can be both physical and mental. 


\section{Abbreviations}

BGB: The Bhagavad-Gitä, with the Commentary of Śrī Śankarächärya. Translated by A.M. Sastry. Madras: Samata Books, 1977; BSB: The Brahma- sutra-bhäșya of Śrī Śankarächärya. 3rd. ed. Translated by Swami Gambhirananda. Calcutta: Advaita Ashrama, 1977; BUB: The Brhadāranyaka Upanișad: With the Commentary of Śankarächärya. 5th ed. Translated by Swami Madhavananda. Calcutta: Advaita Ashrama. 1975; VP: Vedānta -paribhāṣā of Dharmarāja Adhvarīndra. Translated and Annotated by Swami Madhavananda. Calcutta: The Ramakrishna Mission, 1972.

\section{Competing interests}

The author declares that he has no competing interests.

Received: 15 October 2013 Accepted: 15 October 2013

Published: 25 May 2014

doi:10.1186/2196-8802-2-2

Cite this article as: Rambachan: Śabdapramāna : Hindu contributions to understanding the meaning and

function of scripture. International Journal of Dharma Studies 2014 2:2.

\section{Submit your manuscript to a SpringerOpen ${ }^{\circ}$ journal and benefit from:}

- Convenient online submission

Rigorous peer review

- Immediate publication on acceptance

- Open access: articles freely available online

High visibility within the field

- Retaining the copyright to your article

Submit your next manuscript at $\gg$ springeropen.com 